\title{
2
}

\section{What are the legitimate worries about China's WTO membership?}

Wing Thye Woo

There can be no dispute that China's admission into the World Trade Organization (WTO) will result in an important improvement in its external economic security. Trade and foreign investment have constituted an important engine of growth since 1978. The annual review made by the US Congress concerning China's normal trading relationship with the United States has made China's economic growth vulnerable to the vagaries of American domestic politics. Now with WTO membership, the United States will not be able to shut off this engine of growth unilaterally without the action being a major violation of international law.

While the case for external security is clear, WTO membership does raise serious questions about its implications for continued high growth and for internal security. The possibility that WTO membership could be detrimental to China's longterm growth flows directly from the conclusion of some China watchers that the source of China's high growth in the last two decades was a policy of experimentation that had induced unique institutional innovations that were optimal for China's economic circumstances. ${ }^{1}$ From this experimentalist interpretation of China's growth, it is troubling that WTO not only specifies, but also enforces, a common norm on the economic institutions of its members. The logical possibility from the experimentalist perspective is that WTO's emphasis on institutional harmonisation could lower future growth in China.

The possibility that WTO membership could also be detrimental to China's internal security flows from the comprehensive trade deregulation that China has agreed to undertake. The average industrial tariff will fall from 24.6 per cent to 9.4 per cent in 2005 , the average agricultural tariff will fall from 31.5 per cent to 14.5 per cent in 2004, and foreign participation in many service sectors, including telecommunications and banking, will be given national treatment-put on the same legal status as local firms - within five years. Since over a third of all state- 


\section{Dilemmas of China's Growth in the Twenty-First Century}

owned enterprises (SOEs) have been operating with zero or negative profits in the past eight years, and since China with its high man-land ratio is naturally a food importer, the large-scale import liberalisation could result in very high temporary unemployment. This will be politically explosive if not handled correctly.

This chapter seeks to analyse the validity of these worries about China's WTO membership. Our first conclusion is that WTO membership will increase rather than decrease the probability of continued high growth in China. Our second conclusion is that the maintenance of domestic stability is crucially dependent on whether the increase in China's exports and the increase in foreign direct investment into China, can offset enough of the temporary negative unemployment created by import liberalisation.

\section{What is the view from the ivory tower?}

Broadly speaking, there are two schools of thought about the wellsprings of China's growth; the experimentalist school (E-school) and the convergence school (Cschool). ${ }^{2}$ The debate between the two schools started off with different explanations as to why the introduction of market-oriented reforms generated large output collapse in Eastern Europe and the Former Soviet Union (EEFSU) but sustained growth in China. The E-school has ventured the hypothesis that the rapidity and broadness of EEFSU reforms constituted a big negative shock to their economic systems. This hypothesis has fallen out of favour in recent years because the speed and scope of reforms actually varied widely within EEFSU, and there was no relationship between speed-and-scope and degree of output collapse. Furthermore, no such relationship was observed in the communist regimes within Asia. The big-bang style reforms in Laos and Vietnam in 1989 produced higher growth rates instantly and in a sustained manner, while super-gradualist North Korea has veered from one economic disaster to another.

The E-school has recently emphasised that the output collapse in EEFSU was the result of uncritical adoption of western economic institutions that turned out to be inappropriate for the economic circumstances of EEFSU. China, on the other hand, according to the E-school, boldly experimented with different economic institutions and relied on the process of induced innovation to generate new economic institutions that were optimal for its specific economic conditions. Three of the new non-capitalist institutions that are alleged to have produced capitalist-style efficiency without introducing private ownership are

- the introduction of 15-year leases of farmland to households has caused significant productivity increases, thus suggesting that privatisation of farm land is unnecessary

- the introduction of dual-track pricing (sales of above-quota production at market-determined prices) and the devolution of operational 


\section{What are the legitimate worries about China's WTO membership?}

autonomy to the SOEs have improved SOEs' efficiency, suggesting that China has found the right form of enterprise contract that would make market socialism work

- the emergence of rural enterprises that are collectively owned by the local communities and supervised by the local authorities (commonly known as township-village enterprises, TVEs) has produced dynamic growth, suggesting that localised socialism not centralised socialism is the true viable alternative to capitalism.

The convergence school (C-school), on the other hand, sees China's high growth in the 1978-2000 period to be the product of its economic institution being allowed to converge to those of the capitalist market economy. Hence, the Cschool cautions that unless the convergence process is continued, China's growth will slow down in the near future. According to the C-school, China did not adopt standard capitalist market institutions, like in EEFSU, primarily because of ideological and political considerations, and only secondarily because of the desire to discover new economic institutions through experimentation. ${ }^{3}$

In short, the C-school views the so-called new economic institutions identified by the E-school to be political adaptations of the standard institutions in the rich market economies. New growth-generating institutions based on fundamentally different economic principles may appear in China in the future, especially after its full transformation to a market-based economy where all ownership forms are voluntarily embraced. Contrary to the E-school's assertions they claim that no such institutions have been evident in the 1978-2000 period. The C-school points out that

- productivity in the grain sector has slowed down drastically since 1984. The government has responded by lengthening the duration of the land lease from 15 years to 30 years; an action that is consistent with the convergence prediction

- the reform of the SOE sector has failed. ${ }^{4}$ Economic efficiency has not improved, and there is rampant stripping of enterprise assets by managers and workers. As a result the Chinese government is now in the process of privatising all but the largest SOEs; a development that is in line with the convergence hypothesis

- the dynamism of the collectively-owned rural enterprises has flagged considerably since 1991. Most of the collectively-owned enterprises have been corporatised and their shares distributed to the original workers or the original residents. This move toward insider privatisation supports the convergence interpretation.

Possibly because of post 1992 developments in China, some members (and sympathisers) of the E-school have appeared to change their positions, or at least their emphasis, on Chinese economic conditions being the primary reason for the 


\section{Dilemmas of China's Growth in the Twenty-First Century}

unusual nature of these new institutions. These (former) members of the E-school now recognise the imperfect nature of these hybrid institutions, and acknowledge that ideological constraints could have been important factors in determining the non-capitalist characteristics of these hybrid institutions. Despite these changes, the debate between the two schools is still far from over.

To be consistent with the fundamental axiom that it was the newly-discovered economic mechanisms (like localised socialism) that generated the post 1978 growth, the remaining members of the E-school should regard China's joining the WTO, an international organisation that ensures institutional harmonisation, to be a mistake. The logical deduction from the E-school's fundamental axiom is that WTO membership could cause a decline in the future dynamism of the Chinese economy.

To members of the C-school, however, the WTO-induced acceleration in the convergence of Chinese economic institutions to those in rich market economies will sustain China's economic growth in the twenty-first century as long as severe political instability does not occur. The C-school believes that China's deep integration into the international economy will make it politically easier within China to borrow and adapt foreign institutions for its own use. They also believe it will give China the right to help shape the infrastructural institutions that regulate international markets to accommodate its own interests better. The C-school predicts that as a globalised China begins to join the rank of other global economic leaders, the rest of the international community may then re-import from China its adaptations and improved versions of its economic institutions. As the developed China of the future is still likely to account for a quarter of the world's population, and hence its brain power, China will certainly become a significant source of institutional innovations in the world.

\section{The Chinese government's verdict on the debate}

WTO membership marks a watershed in the Chinese government's public recognition of the primary source of its impressive growth in the last two decades. China's willingness to join such an institution reflects its realisation that the active ingredient in Deng Xiaoping's recipe for growth was the convergence of China's economic institutions with the economic institutions of modern capitalist economies, in particular East Asian capitalist economies. At the early stages of China's reform, when most of the intelligentsia did not know the full extent of the economic achievements of their capitalist neighbours, and when most of the top leaders were ideologically committed to Stalinist-style communism, it was important for the survival of the reformist faction of that time that changes to China's economic institutions were comfortingly gradual, conveniently located in areas far from Beijing, and cloaked in the chauvinistic rhetoric, 'experimentation 


\section{What are the legitimate worries about China's WTO membership?}

to discover new institutional forms that are optimal for China's socialist system and particular economic circumstances'.

After 20 years of evolution in economic institutions, rotation in political leadership, and tectonic change in the political fortune of the communist parties in Eastern Europe and the former Soviet Union, the only organised opposition today to the continued convergence of China's economic institutions to international forms comes from a few sentimental Stalinists. ${ }^{5}$ The social and political landscape in China has changed so much that the political leadership now incurs only minimal ideological liability when they introduce more capitalist incentives (such as differentiated pay, leveraged buy-outs, and stock options for managers) and capitalist tools (such as joint-stock companies, bankruptcy laws and unemployment insurance). The leadership is confident that its explicit embrace of capitalist institutions under the auspices of the WTO will be seen by the general Chinese public (and the Chinese elite) as a step forward in the reform process, rather than as the surrender of China's sovereignty in economic experimentation. China's intelligentsia has now gone well beyond the ideologically insecure stage of questioning whether the surname and ancestry of any proposed economic mechanism is socialist or capitalist. They are now at the intellectually confident stage of assessing whether the proposed economic mechanism will increase the productive capacity and resilience of the economy.

The integration of China into the world economy has enabled its exports to industrialise the Chinese countryside, and pay for the import of new technology. The large inflow of foreign direct investments (FDI) has increased the export capacity of the country and enhanced its technological base. Many rigorous studies have confirmed that international integration has been an important reason for the acceleration of growth in China. ${ }^{6}$ Since partial integration has been so favourable for China, total integration will only increase the benefits.

\section{The luck of an initially favourable economic structure}

Luckily for China, economic restructuring was not required in order for growth to occur in the early years of the reform. This is because unlike the urbanised Central European and Russian economies in 1989, which had an overabundance of heavy industries, in 1978 China was still an undeveloped economy dominated by selfsubsistence peasant agriculture. This meant that the introduction of market forces caused economic development in China, but caused economic restructuring in Poland and Russia, which translated, respectively, into output growth and output decline. ${ }^{7}$

The movement of Chinese labour from low-productivity agriculture to higherproductivity industry, and from the poor inland provinces to the richer coastal provinces, produced an average annual growth rate of 10 per cent between 1978 and 1995. The Chinese state sector certainly did not wither away in this period. It 


\section{Dilemmas of China's Growth in the Twenty-First Century}

employed 18.6 per cent of the workforce in 1978 and 18.0 per cent in 1995 , and there were 38 million more state workers in 1995 than in $19788^{8}$ There was a reallocation of labour from agriculture to industry, but reallocation of labour from state to non-state enterprises. China in 1978 was very different from Russia in 1991: while extensive growth was still possible in China, it had run its course in Russia.?

Since China was in the fortunate situation of being able to postpone most of the pain of restructuring, it was understandable that it did so. The result is that after two decades of 'reform and opening,' the job of economic restructuring is far from done. These are some of the many daunting problems that remain

- a government sector that is still too large (despite recent reductions in the central bureaucracy), too intrusive, and susceptible to corruption

- a state-owned enterprise system that has proved itself resistant to numerous efforts to increase its efficiency and profitability

- a state-dominated financial system in which the banks lack the ability to assess the economic merits of proposed projects, and, worse, have shied away from lending to non-state enterprises, the most dynamic component of the economy

- a lack of established institutional infrastructure that allows the smooth running of a market economy-for example, an efficient commercial court system, speedy bankruptcy procedures, independent mechanisms to mediate labour conflict, uniform accounting standards, and social safety nets.

\section{Facing inevitable restructuring}

The trade-off between stability and restructuring so starkly brought to the forefront by China's admission into the WTO is not a new tradeoff. China's WTO membership has accentuated an existing dilemma rather than introduced a new one. The government has always realised that the soft budget constraint of the inefficient state-owned enterprise sector is a constant threat to price stability, and the diversion of resources to keep this sector afloat is a drag on economic growth. But serious restructuring of SOEs means much more than facing higher urban unemployment. It also means confronting the politically powerful industrialmilitary complex and the industrial-bureaucratic complex. Economic rents now pose a bigger obstacle to restructuring than ideological sentimentality, and the rents, unlike the ideology, will not lose their power with the mere passing of time.

The appropriate analogy of China prior to its accession to the WTO, is that of a goat standing at the edge of a chasm. The goat sees that the grass on the other side appears not only greener, but also seems to extend infinitely toward the horizon. The goat also sees a wooden bridge spanning the chasm. The goat faces at least two questions: is the bridge strong enough to carry its weight?; and would it be 


\section{What are the legitimate worries about China's WTO membership?}

able to walk steadily enough on the bridge so it does not fall off?

The analogy is obvious. The goat is China, the grass on its side is the halfreformed centrally planned Chinese economy, the grass on the other side of the chasm is the dynamic capitalist market economy, and the bridge is the WTO. When China signed the trade accord with the United States in November 1999, it has in effect agreed to walk across the bridge to the other side.

\section{Is the WTO bridge strong enough to hold China's weight?}

Entry into the WTO has set in motion two events that could break the beams that are holding the bridge. The first event is the lowering of tariffs. This will increase imports, which could cause the yuan to devalue and raise unemployment in the politically sensitive urban areas. For example, China has over 30 car-making firmsa large number compared to the five in Japan, the most efficient car manufacturer in the world. China is clearly not exploiting the economies of scales in its automobile industry. China's excess capacity exists because the tariff rate on cars, which used to be 200 per cent, is still 100 per cent. But the tariff on cars is scheduled to be drastically lowered in the next five years.

Thus, one of the first consequences of WTO membership could be a flood of imports into China, turning the current account negative, and possibly rendering the present value of the yuan unsustainable. Would a yuan devaluation spark off another Asian currency crisis?

There is, however, another side to this scenario. China's entry into the WTO will not only permit the entry of more imports into China, it will also allow several big Chinese exports greater access to markets in the United States and Western Europe-for example, the multi-fibre agreement is ended. Instead of China losing its shirt because of its entry into the WTO, the Chinese textile industry would expand. Labour-intensive exports will expand more generally to offset some of the increase in imports.

In the event that the current account does turn negative, it still need not be a source of serious concern. After the November 1999 signing of the Sino-United States trade accord, there has been a sharp rise in the contracted FDI into China. The capital account is expected to show a much larger surplus than before, and this is likely to keep the overall balance of payments in surplus, allowing the yuan peg to be sustainable.

What if the preceding prediction is wrong and China's balance of payments does turn negative? At that point, it would not be a bad thing for the yuan to be devalued, for all of China's biggest competitors have experienced devaluation from 1997-2000. China did not have an excuse to devalue during the 1997-2000 period because its trade account and capital account were positive. Had China devalued the yuan to take into account what had happened in Southeast Asia, the 


\section{Dilemmas of China's Growth in the Twenty-First Century}

United States Treasury and the IMF, among others, would have accused it of exchange rate manipulation. In the unlikely event of a devaluation of the yuan in the aftermath of tariff cuts, it is unlikely to cause competitive devaluations across Asia, because the market will take into account that the tariff cuts would also open China's markets to the Southeast Asian economies, resulting in no major loss of competitiveness for these economies.

Another important issue arising from tariff reductions is the loss of jobs, which could translate into political instability. The net loss of jobs depends on two factors: how large the rise in exports will be in the face of better market access to the foreign markets; and, how large the job creation will be from the increase of FDI into China? As long as these two factors are substantial, the loss of jobs will not be as disastrous as some commentators have suggested. Since 1994, China has been laying off workers in the small to medium SOEs on a large scale. Most of the industrial northeastern provinces have had relatively high rates of unemployment for the last five years, and yet social stability has been maintained. From this post 1994 experience, the government appears confident that it is sufficiently capable of containing the domestic disturbances from higher unemployment.

Besides tariff reduction, another post WTO event that could knock off one of the bridge's beams, is the entry of foreign-owned banks into China. One of the aspects of the trade agreement that has always been commented upon with some surprise, is how much the Chinese appear to have conceded in the financial sector. The question is whether the WTO will finally bring about the meltdown of the state-banking system as the newsletters of some Hong Kong based investment banks have been predicting since 1997. The bank meltdown scenario is based on the fact that all the state banks are effectively insolvent (Lardy 1998). Hence, there is the danger that depositors, realising the insolvency of the banks, would start a run for the deposits and precipitate a credit crisis that would reduce production and create a recession. This is the oft-predicted gloom-and-doom scenario that has not happened. Now, with WTO membership, will competition from foreign-owned banks make the insolvency of the state-banks so obvious to the general public, that the long-expected bank run will at last occur?

It is far from Panglossian to state that even if the profits of the state banks are further decreased, thereby worsening their insolvency, this situation is well within the technical capacity of the Chinese government to handle. A run on the Chinese banking system is a run from M2 to M0 (M2 is cash plus banking deposits and M0 is cash). This transformation from M2 to M0 need not cause the banks to fail, as it could easily be accommodated by the central bank acting as the lender of last resort to the banks. The banking crisis takes a more serious turn only if the increase in M0 is switched into foreign currencies, because then the exchange rate would plummet. But, given the existing capital controls in China, the switch from M0 into foreign currencies cannot take place, and the exchange rate will not collapse. 


\section{What are the legitimate worries about China's WTO membership?}

Because M0 cannot run into foreign currencies, it could run into goods. The frightful scenario is that this would spark off an inflation that would decrease the willingness of the Chinese government to accommodate the bank run. However, given that China is still in a deflationary situation and is expected to remain so in 2001 , inflation would not take off even it there were a run from M0 to goods. In a weak domestic economy, it is a good thing if people run from M0 to goods because this will boost aggregate demand.

The last technical detail is that since MO cannot run into the US dollar, and if M0 does not run into goods, it will then have to run under the pillows. Money under the pillows is good news because it means that the crisis will soon blow over, provided that the central bank has prevented any bank from failing during the bank run and, hence, has avoided undermining public confidence in the government's commitment to ensuring the safety of bank deposits. Just leave the M0 alone under the pillows, and it will, like Little Bo-Peep's sheep, return to the banks with their tails behind them.

\section{Can China walk steadily on the WTO bridge?}

The basis for this question is that the Chinese economy has recently been proceeding unsteadily on two fronts. China has been wobbling on the macroeconomic front because it has found it exceedingly hard to utilise the traditional instruments of macroeconomic stabilisation. China has also been wobbling on the political front because of the difficulties of reforming the state enterprise sector.

China's wobbly gait on the macroeconomic front is caused by two Keynesian maladies; the liquidity trap and the paradox of thrift. The liquidity trap refers to the phenomenon of the last few years where monetary policy does not seem to work. China has tried to boost the domestic economy with successive cuts in interest rates, but the rise in credit creation has been disappointing. Credit growth has been much lower than expected, except for brief intervals when the central bank leaned heavily upon the banks.

The paradox of thrift refers to the steady decline in private aggregate demand because the private saving rate has been increasing. The Chinese government has concluded that, because private aggregate demand is falling and monetary policy seems incapable of stimulating it, the key to maintaining macroeconomic stability is government spending.

However, fiscal stimulus may not be the most efficient way to deal with the current problem of weak domestic demand. The solution lies in eliminating the liquidity trap and ending the paradox of thrift. I argue that both of these phenomen spring from the same cause, which is the absence of adequate financial intermediation in China.

Why is China suffering from the liquidity trap? State bank managers have 


\section{Dilemmas of China's Growth in the Twenty-First Century}

been told that if the ratio of non-performing loans were to go up in two consecutive years, they will lose their jobs. The traditional client-base of the state banks is state enterprises, of which, half to two-thirds, are reporting zero or negative profits. By extending more loans to state enterprises, the non-performing loan ratio will inevitably rise.

At the same time, and for very good reasons, state banks are also unwilling to lend to non-state enterprise. First, the accounting practices of the non-state enterprises are neither uniform nor transparent. Second, it is politically more risky to do so. A loan to a state-owned enterprise may be a bad economic decision, but a loan to non-state enterprise that goes bad could also be a potentially bad political decision. A bank manager could be accused of consorting with the private sector to embezzle the state.

The Chinese government has sought to increase bank lending to private individuals by encouraging banks to establish mortgage loans, which are perceived as less risky because of their seemingly fully collateralised nature. Mortgage lending, however, is a totally new product to be provided to a totally new set of customers, and so the state banks have, understandably, been slow in setting up this market.

The liquidity trap arises because the banks are not willing to lend money to either SOEs or the private enterprises. The only activity that the banks are happy to use their funds for is buying the state bonds to finance the government's deficit spending. The fundamental step to eliminating the liquidity trap is to end the bias against lending to the private sector.

In the paradox of thrift, some observers have interpreted the rise in the saving rate to be a sign of general pessimism by the Chinese public. These observers claim that urban workers are afraid of losing their jobs as a result of the forthcoming state enterprise reform. With the forthcoming cancellation of free housing, free medical care and subsidised education, workers are now saving more for the future. There is something wrong with this reasoning - there has also been a rise in the rural saving rate, which should not be the case if this line of reasoning were correct. This is because rural residents have little to fear about the loss of jobs in the stateenterprise sector as none of them are employed there. They do not have to fear losing free housing because they have never had free housing. They do not have to fear losing their pension and other subsidies because they have never had it.

The reason why the rural sector has increased its savings rate is quite straightforward. The most dynamic industrial expansion in China since 1984 has occurred in the rural areas. Since non-state firms in the rural areas cannot borrow from the bank, the only way they could establish themselves was through selffinancing, which required the would-be entrepreneurs to save first. In the initial phase of rural industrialisation, the amount of capital that was needed to start a factory workshop was very low. After 16 years of rapid industrial growth, the Chinese countryside is saturated with labour-intensive enterprises. Competition 


\section{What are the legitimate worries about China's WTO membership?}

is fierce. It now makes no sense to invest and open the same type of factory workshop, and rural enterprises have to move up to the next stage of value added production. This new generation of rural enterprises will be much more capitalintensive, thus requiring a much larger amount of startup investment.

Rural residents have responded to the higher capital requirements by increasing their saving rates. The rising rural saving rate reflects optimism about the future. This phenomenon of investment-induced savings is not new, ${ }^{10}$ it has happened earlier in Taiwan. Up until the mid 1980s, all Taiwanese banks were state-owned. Every Taiwanese loan officer was personally responsible for any loan that went bad, and so every loan officer minimised lending to small and medium sized enterprises, and only lent readily to big business groups. Between 1960 and 1985, there was a steady rise in the saving rate in Taiwan.

Total fixed investment was 30 per cent of GDP in 1987, and 33 per cent of GDP in 1997. It rose 3 percentage points in 10 years. Fixed investment in the rural sector was 9 per cent of GDP in 1987 but was only 8 per cent in 1997. The investment-GDP ratio went up at the national trend, but went down in the rural sector, the most dynamic part of the Chinese economy. The investment ratio in the rural sector has gone down because it makes no sense to establish another labour-intensive factory, and rural entrepreneurs cannot borrow the money to undertake the more capital-intensive investments required for the next generation of rural enterprises. The investment-GDP ratio went up at the national level because FDI went up while state investments (through either the budget or state enterprises) utilised the domestic savings fully.

The solution to insufficient domestic demand in the Chinese economy is not for the government to use up the private savings in public investments, but to set up mechanisms to channel private savings into private investments. This is where the entry of foreign banks will be exceedingly important. Foreign banks will be concentrating their activities in the large coastal cities, where the state-owned banks now make the bulk of their profits. This increased competition will force the state-owned banks to focus on areas of banking where they have a comparative advantage over the foreign banks; in the inner provinces and the rural areas where they have extensive existing branch systems. The state banks have traditionally neglected the inland provinces and the rural areas. The most dynamic part of the Chinese economy is located in the rural areas, and yet formal financial intermediation has decreased there-the number of rural banks has actually decreased in the 1985-95 period. This trend is directly against the sustenance of growth, and has occured because the regulated interest rate for loans in China made it unprofitable to extend small loans. Large and small loans require the same amount of paperwork and time to process. It is only natural that rural banks should charge a higher interest rate since the cost of monitoring and processing the loan is higher. But since rural branches have to charge the same lending rates 


\section{Dilemmas of China's Growth in the Twenty-First Century}

on small loans as urban branches on large loans, banks have retreated from lending in the rural areas. The liberalisation of interest rates combined with increased competition in the coastal urban markets will motivate the state banks to expand their activities in the long-neglected inland provinces and rural areas.

What has happened in the face of strong rural industrial growth is that a lot of informal rural financial institutions have sprouted up to meet the financing needs of the rural industries. Given the illegal nature of these rural financial institutions, they live under constant threat of closure, and so tend to focus only on the short run and take more risks. It is not surprising that these risky rural financial institutions often fail. Whenever they fail, the government has to bail them out in order to maintain political stability. Subsequently, the government has been clamping down even harder on these illegal financial intermediaries, as it does not want to choose between the risk of bailing them out or the risk of social instability. The government's increasingly strict enforcement of the ban on private financial intermediation is exactly the opposite to what ought to be done. The efficient solution is to allow private financial intermediaries in the rural area, and bring them under proper prudential supervision.

The general principle, and a trend that the Chinese government will find increasingly costly to prevent, is to reduce interest rate controls and allow private banks to come into existence. The improvement in financial intermediation will eliminate the liquidity trap and reduce the paradox of thrift. The entry of foreign banks will also improve financial intermediation by enabling the transfer of modern banking technology through a seldom-mentioned channel. In the future, when a successful Chinese enterprise group establishes a bank, it will do so by hiring the local managers employed by the foreign owned banks. This has been the Southeast Asian experience, where the top managers of all the biggest domestic banks were all ex-employees of foreign banks. This is perhaps what the Chinese leadership sees and why it is willing to allow the entry of foreign banks, giving them national treatment within five years of WTO membership. The Chinese leadership is betting that in the short run, there could be significant displacement of Chinese state banks by foreign banks, but in the long run, Chinese banks (most likely private ones) will increase in importance. Twenty years from now, the international financial world will have more to fear from Chinese banks than vice-versa.

China's walk across the bridge is also wobbly because of the uncertainty as to how the privatisation process should continue. The state enterprise sector is simply too large, and, like its cousins the world over, is losing money on a large scale. Most state enterprises are already economically dead. Obviously, the Chinese leadership agrees with this description, because it has been expanding SOE privatisation. But the Eastern European experience warns that mass privatisation is an exceedingly dangerous business politically no matter how it is done, be it outsider privatisation through vouchers as in the Czech Republic or insider 


\section{What are the legitimate worries about China's WTO membership?}

privatisation through shares for loans as in Russia.

Corruption leading to political demise appears to be an inevitable by-product of mass privatisation, for example Vaclav Klaus in the Czech Republic and Anatoli Chubais in Russia. China has so far avoided widespread organised public dissatisfaction with its partial privatisation of the small and medium state enterprises. The central government has given itself an indirect role in the privatisation process in order to avoid bearing the brunt of any negative fallout. It works through passing to local governments the financial responsibility for most of the state enterprises located in their areas. In the case of loss-making enterprises, the local government is forced to either come up with a subsidy or to privatise them. The second option is the common choice. The party secretary who gets rid of the loss-makers without arousing local resentment is promoted. If there is substantial public resentment over the privatisation, then the party secretary is reprimanded or replaced for inept implementation of state policy.

The question is whether this strategy can continue to shelter the central government from the public backlash over inept privatisation, especially when the large state enterprises are privatised? Given the fact that every manager, after the implosion of the Soviet Union in 1991, knows that privatisation is inevitable, he recognises that this is the last chance for him to steal. This end game consideration may be responsible for the recent escalation of corruption across China, creating a situation that Party Secretary, Jiang Zemin, has called the biggest threat to the continued rule of the Communist Party. In short, the ongoing acceleration of the privatisation process (both formal and informal) could create a political storm over corruption that would make it difficult for China to walk steadily across the bridge to the greener grass of a private market economy.

\section{Conclusion}

It is important to be reminded that the apparent trade-off faced by China between stability and restructuring is not caused by its accession to WTO membership but by the need to move from a planned economy to a market economy. Joining the WTO now is really not bringing forward the date of confronting this trade-off. Most SOEs have been economically dead for almost a decade, and the fiscal burden and the corruption problem of the state enterprise sector have become too heavy to bear. ${ }^{11}$ The two key WTO-induced developments that are crucial to the successful crossing of the WTO bridge are the rise in Chinese exports and the rise in FDI. Their occurrence will improve the tradeoff in the state enterprise sector between restructuring and job losses.

While keeping balance on the macroeconomic and political fronts would enable China to walk steadily across the bridge, we must point out that the absence of a strong wind is also crucial for making it over to the other side. There are three 


\section{Dilemmas of China's Growth in the Twenty-First Century}

types of typhoon that would make the crossing more difficult for China.

- Substantial slowdown in the US economy: the US economy has been the engine of growth for the world economy. Recent data suggest that continued fast expansion of the United States economy is unlikely. Japan seems likely to plunge back into recession. Western Europe shows no signs of dynamic growth that would rival that of the United States. So, a significant slowdown of the US economy means that there would be a fall in Chinese exports and a drop of FDI into China, both of which are important for keeping the bridge strong enough for the goat to walk on. More importantly, the slowdown in the United States economy could give impetus to protectionism within the United States, and this would make the WTO adjustment process in China much more painful.

- Political conflicts in the Pacific Rim: three such conflicts come readily to mind: the Chinese occupation of islands in the South China Sea; mainlandTaiwan tensions over political union; and the resolution of the Korean question, if the North Korean regime were to collapse from a worsening of its already disastrous economic situation. In the case of an acrimonious political conflict, trade sanctions by the United States and other Western European countries will hamper Chinese economic performance.

- Drop in FDI: FDI in China may not grow as rapidly as expected. This scenario depends on changes in the attractiveness of places like India. India has been unusually hostile to FDI - for example, foreigners cannot hold more than 51 per cent of equity in a firm. If this were to change, a significant diversion of FDI into India, a country with an Englishspeaking labour force, could happen.

\section{Acknowledgments}

I am grateful Ligang Song and Wei Men of The Australian National University, and Geng Xiao of the University of Hong Kong for very helpful conversations on the Chinese economy, the reform of state-owned enterprises, and the impact of WTO.

\section{Notes}

1 Prominent examples of this experimentalist line of thought are Naughton (1994) and Rawski (1995).

2 Sachs and Woo (2000) surveys this debate in detail.

3 Chang and Wang (1994) is an early recognition of this point.

4 Chen (1998) provides an excellent picture of the difficulties in reforming SOEs in her case study on Chongqing. One of her most interesting findings is that new managers bring improvements in the first two years but then they begin to focus on asset-stripping. 


\section{What are the legitimate worries about China's WTO membership?}

5 For recent warnings from this faction against what is perceived as suicide by the Communist Party, see 'Elder warns on economic change', South China Morning Post, 13 January 2000, and 'Leftists make late bid to slow reforms', South China Morning Post, 10 February 2000.

6 For a recent study on the large impact of FDI on China's growth, see Demurger (2000).

7 This argument is developed in Sachs and Woo (1994).

8 The 18.0 per cent for 1995 is calculated from the China Statistical Yearbook 1996 because the total workforce data from 1990 onward was revised upward in the China Statistical Yearbook of the succeeding years by increasing the size of the rural workforce. The revised data are inconsistent across time. The growth in labour force between 1989 and 1990 is now 15.5 per cent (!), while the old data show an increase of 2.5 per cent. Using the revised data, the SOEs employed 17 per cent of the total labour force.

9 Easterley and Fischer (1994) shows that extensive growth came to a quicker end in Russia than would have occurred in capitalist market economies because the elasticity of substitution between capital and labour in Russia was much lower. Woo (1998) suggests that the intersectoral reallocation of labour contributed 1.3 percentage points to the annual GDP growth rate in the 1985-93 period.

10 See Liu and Woo (1994) for theoretical discussion and empirical verification of investment-induced saving.

11 The combination of mounting losses in the state enteprises, the inability of the government to raise revenue significantly, and the need to increase state spending to maintain aggregate demand is creating a fiscally alarming situation. See Gamble (2000) on the difficulties of tax collection in China. 